\title{
Kelekatan Ibu Bekerja Pengaruhnya Terhadap Kesejahteraan Psikologis Remaja
}

\author{
Syarifah Farradinna \\ Fakultas Psikologi, Universitas Islam Riau, Pekanbaru \\ syarifah.farradinna@psy.uir.ac.id
}

\begin{abstract}
Abstrak
Secara umum, ibu yang bekerja berkaitan dengan kesehatan mental yang lebih baik dan memberikan keuntungan bagi remaja. Tujuan penelitian ini adalah menguji pengaruh kelekatan ibu bekerja-remaja terhadap kesejahteraan psikologis. Pemilihan subjek dalam penelitian ini adalah remaja dalam kelompok usia 15 sd 19 tahun, sebanyak 352 telah terpilih secara sukarela. Penelitian ini menggunakan alat ukur dari skala Inventory of Parent and Peer Attachment (IPPA) adaptasi dari Greenberg (2009) dan skala kesejahteraan psikologi yang dikembangkan oleh Ryff \& Keyes (1995). Analisis statistik yang digunakan dalam penelitian ini adalah korelasi Spearman $\left(\mathrm{r}_{s}\right)$. Berdasarkan analisis yang telah dilakukan kepercayaan remaja pada ibu yang bekerja berhubungan signifikan positif dengan aspek kelekatan komunikasi dan kesejahteraan psikologi. Kehadiran orang tua, dalam hal ini Ibu pada saat dibutuhkan adalah fitur kunci dari kelekatan aman pada individu terutama remaja, membangun kualitas komunikasi dua arah antara ibu dan remaja membantu meningkatkan kesejahteraan psikologis remaja.
\end{abstract}

Kata kunci: kelekatan; ibu bekerja; kesejahteraan psikologis; remaja

\section{Pendahuluan}

The International labor Organization menyebutkan bahwa 70 persen wanita-wanita dinegara maju telah terlibat dalam ekonomi global, dan begitu pun dengan negara-negara berkembang juga dilaporkan bahwa sebanyak 60 persen wanita yang telah menikah dan memiliki anak mengambil bagian dalam perekonomian keluarga. Secara garis besar peningkatan wanita yang melibatkan diri dalam pekerjaan diluar rumah terus mengalami peningkatan yang dramatis, pada tahun 2011 telah dilaporkan bahwa kenaikan partisipasi wanita dalam pekerjaan sebesar 0.65 persen dari tahun 2007 sebesar 42.4 persen menjadi 46.5 persen pada tahun 2011. Namun demikian, Laporan dari Badan Pusat Statistik (2013) mencatat sebanyak tingkat partisipasi angkatan kerja pada wanita sebesar 
53.46\% pada tahun 2013, mengalami penurunan daripada perhitungan Februari tahun 2012 sebesar 56.05\% namun demikian jumlah ini tetap berada pada angka diatas daripada 50 persen. Data kementerian pemberdayaan perempuan dan perlindungan anak melaporkan bahwa para ibu bekerja telah menggunakan waktu mereka selama 40 jam perminggu nya selama lima hari untuk menyelesaikan pekerjaan mereka ditempat kerja, yang disertai dengan fasilitas dan kompensasi yang memadai (KeMenP2A, 2013).

Ibu bekerja telah menghabiskan banyak waktu dalam menyelesaikan tugas-tugas dari tempat kerja, para ibu bekerja berusaha untuk melaksanakan kedua-dua peran dalam satu interaksi keseimbangan peranan agar dapat menghasilkan kesejahteraan (Nomaguchi et al, 2005). Penelitian sebelumnya melaporkan bahwa tumbuh kembang yang sehat dilakukan secara konsisten dan memiliki hubungan yang stabil bersama orang tua yang responsif memungkinkan anak dan remaja untuk mengeksplorasi diri tanpa resiko atau takut bahaya, memiliki gizi yang cukup dan perawatan kesehatan yang memadai (Heinrich, 2014). Selain itu, ibu bekerja telah dibuktikan memiliki pengaruh yang baik kepada anak-anak usia sekolah membekali mereka dengan sikap otonomi, dan memiliki kualitas merawat anak-anak lebih baik. Walaupun demikian, penelitian terdahulu tidak banyak menunjukkan hasil penelitian pada ibu-ibu bekerja yang memiliki remaja usia sekolah menengah dan memasuki masa dewasa.

Secara umum, ibu yang bekerja berkaitan dengan kesehatan mental yang lebih baik dan dapat memberikan keuntungan bagi anak-anak, khususnya remaja karena adanya penghasilan tambahan dan stimulasi sosial dan kognitif sehingga mewujudkan interaksi yang lebih positif dan menjaga kualitas kelekatan dengan anggota keluarga (Kalil \& Siol-Guest, 2004). Remaja yang memiliki ibu bekerja memandang sebagai perilaku model positif, yang diprediksi dapat meningkatka prospek pekerjaan ibu dimana depan (Heinrich, 2014). Walaupun beberapa penelitian lebih banyak menghasilkan laporan efek positif dan negatif ibu bekerja yang memiliki anak usia prenatal sampai usia sekolah dasar (Loopo, 2004; Kalil \& Siol-Guest, 2004; Gennetian \& Miller, 2002). Penelitian ini akan berfokus kepada studi yang baru dalam menjawab gap dari peneliti-peneliti sebelumnya 
berkaitan dengan kesejahteraan remaja yang memiliki ibu bekerja seperti $\mathrm{Pu}$ (2008) dan Montemayor \& Clayton (2001), penelitian saat ini akan lebih menjelaskan kesejahteraan psikologi pada remaja yang akan melalui masa fase dewasa awal, yang akan terangkum dalam beberapa bagian penjelasan.

Tujuan peneliti melakukan penelitian ini lebih lanjut adalah guna mengidentifikasi kesejahteraan psikologis remaja yang memiliki ibu bekerja berdasarkan faktor demografi (jenis kelamin, umur, jenis pekerjaan ibu, dan beberapa faktor demografi lainnya). Memberikan gambaran pengaruh kelekatan ibu bekerja-remaja terhadap kesejahteraan psikologis.

\section{Kesejahteraan Psikologis}

Berbagai pendapat telah menjelaskan definisi dari kesejahteraan, seperti Ryff \& Keyes (1995) menjelaskan konsep kesejahteraan berasal dari analisis yang komprehensif berbagai pendekatan untuk mencapai kebahagiaan. Perubahan makna kesejahteraan tidak terlepas dari serangkaian pengaruh definisi emosi positif. Umpan balik fungsi emosi positif menjelaskan keadaan yang tidak mengancam dan membangkitkan ketahanan dengan lebih luas pada seluruh aspek kehidupan (Ryff et al, 2004). Reaksi emosi positif menujukkan yang stabil mampu menguraikan efek jangka panjang kepada kesejahteraan terhadap lingkungan (Lybomirsky et al 2005). Walaupun disejajarkan dengan kesenangan, prinsip kesejahteraan telah diteliti oleh para ahli lebih mendekati kepada kepuasan hidup, berbanding dengan prinsip kesenangan (Ryff \& Keyes, 1995).

Sejalan dengan waktu, kesejahteraan psikologi mengalami perubahan makna, yang disebabkan adanya perubahan pandangan dan integritas mengenai hal tersebut. Deklarasi Kesehatan Mental Eropa tahun 2005 menyebutkan punca menurunnya produktivitas kerja dikarenakan adanya penurunan kesejahteraan psikologis individu. Serangkaian pengaruh positif, dan penurunan pengaruh negatif didefinisikan sebagai kesejahteraan psikologi, ini terjadi karena adanya peralihan sumber-sumber fisik dan psikologis dari kehidupan seorang individu (Bradburn 1996). Pengaruh positif dari kesejahteraan psikologi berhubungan dengan kemampuan individu mengontrol tekanan-tekanan dari lingkungan psikososial nya (BPS 2010). Studi ini pun dibenarkan oleh pendapat lain bahwa 
kesejahteraan psikologi merupakan keseimbangan antara pengaruh positif dan negatif dalam merespon situasi dan keadaan lingkungannya (Boniwell \& Henry, 2007).

Studi kesejahteraan seterusnya dikembangkan oleh beberapa ahli, salah satu nya adalah Ryff \& Singer (1996) yang menjelaskan bahwa integrasi teori perkembangan kesehatan mental, klinis dan kehidupan sepanjang hayat dirujuk berdasarkan beberapa aspek konvergen dari teori fungsi psikologi positif. Kesejahteraan psikologi dikemukakan oleh ahli terdahulu membedakan pandangan dengan subjektif kesejahteraan melalui pendekatan multidimensional yang terdiri atas enam aspek aktualisasi manusia (Ryff \& Keyes, 1995). Keenam konstruksi kesejahteraan psikologi ini, secara teoritis maupun operasional diprediksi mampu menentukan dan menunjukkan ciri kesehatan emosional dan fisik, ini dijelaskan oleh seorang ahli kesejahteraan psikologi seperti Ryff \& Singer (1998). Hasil penelitian telah menunjukkan bahwa eudaimonic yang diwakili oleh kesejahteraan psikologi dapat mempengaruhi sistem fisiologis tertentu yang berkaitan dengan fungsi kekebalan dan kenaikan taraf kesehatan.

\section{Kelekatan ibu bekerja-remaja}

Teori kelekatan adalah teori psikologi, evolusi, dan etologis mengenai hubungan antara manusia. Teori ini dikembangkan pertama kali oleh John Bowlby pada tahun 1930-an, beliau bekerja sebagai seorang dokter kejiwaan di pusat bimbingan klinik anak di London, Britania Raya. Ini bermula ketika banyak anak-anak yang mengalami gangguan emosi, sehingga Bowlby merasa perlu mempertimbangkan hubungan emosional dan kognitif antara ibu dan anak selama perkembangan sosial nya. Bowlby mendefinisikan kelekatan sebagai hubungan emosional yang mendalam dan abadi, yang mana telah dibangunkan antara anak dan ibu/yang dipanggil ibu dalam periode waktu tahun-tahun pertama kehidupan anak. Menurut Bowlby kelekatan merupakan bahagian sangat penting dalam kelangsungan hidup biologis individu, kecenderungan berperilaku untuk mendapatkan respon Ibu. Kualitas dan seberapa besar respon yang diberikan merupakan faktor utama dalam menunjukkan kelekatan anak dengan Ibu. 
Sumber selain ibu/orang tua merupakan dukungan yang sama penting seperti teman sebaya, karena hal ini berkaitan dengan kemampuan eksplorasi remaja dalam mengeksplorasi ide-ide baru, penerapan nilai-nilai dan gaya hidup, tetapi masih mendapatkan kehadiran dan bergantung pada basis rasa aman dari ibu/pengasuh dalam segala kehidupan (Albert, Trommosdoff, \& Mishra, 2007). Perubahan gaya kelekatan pada masa remaja, tentunya terdapat beberapa perbedaan dari masa anak-anak. Ini terbukti perubahan dalam hubungan ibu-anak pada masa remaja menjalankan hubungan kelekatan yang lebih mengarah kepada simbiosis. Anak-anak memiliki hubungan kelekatan yang baik, dan tetap memiliki hubungan yang stabil dengan teman sebaya (Rothbaum, Weisz, Miyake, \& Morelli, 2000). Kenyamanan fisik dan perawatan yang peka merupakan hal yang penting untuk mencapai kepercayaan dasar pada individu, menumbuhkan kepercayaan ini adalah basis bagi menciptakan kelekatan dan harapan bagi individu dalam memandang alam sekitarnya.

\section{Metode}

Penelitian dijalankan dengan menggunakan pendekatan kuantitatif untuk mengidentifikasi variabel kelekatan ibu bekerja dan kesejahteraan psikologi remaja. Prinsip analisis korelasi dan regresi digunakan untuk mengukur sejauhmana hubungan dan pengaruh kelekatan ibu bekerja terhadap kesejahteraan psikologi remaja.

Subjek penelitian

Subjek sasaran dalam penelitian ini adalah remaja yang memiliki ibu bekerja sebagai karyawan, pelaku usaha, guru dan aparatur sipil negara. Oleh karena populasi sasaran remaja bersifat tak terhingga yaitu populasi yang memiliki sumber data yang tidak ditentukan batas-batas kuantitatifnya. Berdasarkan data statistik dari Badan Pusat Statistik (BPS) tahun 2014 diketahui jumlah penduduk kota Pekanbaru menurut kelompok umur 15 sd 19 tahun berjumlah 99.341 orang. Dengan demikian, subjek sebagai sasaran penelitian ini dijalankan kepada remaja usia 16 sd 20 tahun. Berdasarkan teori Slovin dengan taraf signifikan 5 persen, diketahui jumlah sampel dalam penelitian ini sebanyak 
398,395 orang atau ditetapkan sebanyak 398 orang. Sebanyak 117 (33.2\%) orang remaja laki-laki dan 235 (66.8\%) orang remaja perempuan, berkisar umur 16 sd 20 tahun. Sebagian besar pendidikan terakhir ibu adalah Sekolah Menengah Atas (SMA)/Sekolah Menengah Kejuruan (SMK), sebanyak 50.3\%. Sedangkan ibu yang telah menyelesaikan program sarjana strata 1 sebanyak $36.1 \%$, tingkat pendidikan ibu lainnya tersebar di Diploma dan Sekolah Menengah Pertama (SMP).

\section{Instrumen penelitian}

Penelitian ini menggunakan dua skala pengukuran, yang mana kedua skala pengukuran ini terdiri dari:

a) Skala kelekatan

Teori kelekatan telah dibangun oleh beberapa konstruk dari beberapa ahli yang melakukan penelitian tentang kelekatan, diprediksi teori kelekatan telah turut membentuk dasar dari terapi dan informasi, serta konsep yang digunakan dalam merumuskan kebijakan sosial dan mendukung hubungan keterikatan/kelekatan awal pada anak-anak (Bowlby, 1982). Variabel kelekatan diukur dengan menggunakan skala yang telah dikembangkan dan diuji oleh peneliti sebelumnya iaitu Armsden \& Greenberg (2009) yang diberi judul Inventory of Parent and Peer Attachment (IPPA). Alat ukur IPPA ini telah dikembangkan untuk menilai persepsi remaja terhadap afektif/dimensi kognitif yang positif dan negatif hubungan nya dengan orangtua, dalam penelitian ini hanya ditinjau kepada hubungan dengan ibu yang bekerja, ini didasarkan kepada seberapa baik skor yang diperoleh sebagai sumber keamanan psikologisnya.

Skala ini telah diuji coba dan dilakukan pengambilan ata penelitian kepada sekelompok remaja dalam usia 16 sd 20 tahun. Instrumen ini terdiri dari tiga aspek pengukuran yang disertai dengan penilaian skor positif dan negatif iaitu kepercayaan remaja terhadap ibu, salah satu pernyataan positif adalah "Ibu menghargai perasaan yang sedang saya alami”, sementara contoh pernyataan negatif seperti "Saya berharap saya memiliki ibu yang lain". Aspek kedua iaitu 
komunikasi remaja kepada Ibu, salah satu contoh pernyataan nya seperti "Saya menyukai apa pun yang disukai ibu". Sedangkan contoh pernyataan negatif yang diberikan seperti "Saya merasa tidak ada gunanya menunjukkan perasaan yang saya rasakan kepada ibu". Aspek pengukur ketiga ialah pengabaian penglibatan ibu, yang mana keseluaruhan pernyataan dalam pernyataan negatif seperti "Menceritakan masalah saya kepada ibu membuat saya menjadi malu dan tampak bodoh". Adapun format pengisian yang dapat dilakukan adalah dengan memilih salah satu pilihan jawaban yang sesuai dengan yang dirasakan oleh subjek terhadap Ibu atau seseorang yang berperan sebagai Ibu (Ibu kandung, ibu tiri, ibu wali, dll), format pengisian yang digunakan adalah 5-poin skala Likert.

b) Kesejahteraan psikologi

Variabel kesejahteraan psikologi dalam penelitian ini merupakan salah satu dari variabel terikat yang akan diteliti. Kesejahteran psikologi telah dibangun dan dikembangkan oleh beberapa peneliti kesejahteraan psikologi dalam beberapa penelitian terdahulu iaitu menjelaskan sejauhmana kualitas emosi positif individu mencapai keuntungan atau kepuasan ketika berhadapan dengan perubahan situasi yang kemudian bertahan hidup dengan standar penyelesaian yang ideal dan layak (Ryff \& Keyes, 1995; Veenhoven, 1991) sehingga individu dapat beradaptasi dengan lingkungan.

Model kesejahteraan psikologi ini telah dibina sehingga dapat menunjukkan satu gambaran diri pada setiap aspek pengukuran dimensinya yang terdiri dari autonomy (Bahagia menjadi diri sendiri, tanpa menunggu persetujuan orang lain), environmental mastery (Saya sangat sesuai dengan orang-orang dan masyarakat disekitar saya), personal growth (Saya tertarik dengan kegiatan yang mempeluas wawasan pengetahuan saya), positive relations with others (Saya menikmati kebersamaan dengan teman-teman dan keluarga), purpose in life (Saya menetapkan tujuan hidup dengan menghargai nya), dan self-acceptance. Setiap (Saya memandang positif diri saya, seperti orang lain memandang positif dirinya) butir soalan telah dilakukan modifikasi, tanpa merubah maksud dan artinya, dengan mengikut ketentuan bahasa Indonesia, oleh ahli Bahasa Inggris dan 
Bahasa Indonesia, yang mana respon yang dapat ditunjukkan oleh partisipan terdiri dari 6 kategori skala 6-1 (6 = sangat setuju, dan $1=$ sangat tidak setuju). Oleh karena itu, responden yang didapati skor rendah pada skala kesejahteraan psikologi menunjukkan bahwa mereka tidak menunjukkan kesejahteraan psikologi yang baik. Sebaliknya, skor tinggi pada skala ini menggambarkan kesejahteraan psikologi yang baik.

\section{Hasil dan Pembahasan}

Proses pengumpulan data yang telah dilakukan dilanjutkan dengan mengulas hasil dan memaparkan hasil lebih lanjut. Adapun analisis yang dijalankan ini menjelaskan hasil analisis dari deskripsi subjek penelitian, reliabilitas dan validitas, deskripsi skor indikator pengukuran, uji asumsi dan hipotesis.

\section{Validitas dan Reliabilitas}

Berdasarkan tabel 1 menunjukkan analisis deskriptif diperoleh skor reliabilitas dan validitas pada setiap aspek pengukuran kelekatan ibu bekerja dan kesejahteraan psikologi remaja adalah sebagai berikut:

Tabel 1. Validitas dan reliabilitas skor per aspek pengukuran

\begin{tabular}{cccc}
\hline Variabel & Skor validitas & Skor reliabilitas & Keterangan \\
\hline Kepercayaan (trust) & 0.761 & 0.806 & Tinggi \\
Komunikasi & 0.792 & 0,803 & Tinggi \\
Pengasingan & 0.041 & 0.735 & Sedang \\
(alienation) & 0.931 & 0.784 & \\
Autonomy & 0.918 & 0.774 & Sedang \\
Environmental Mastery & 0.895 & 0.828 & Sedang \\
Personal Growth & 0.930 & 0.790 & Tinggi \\
Self Acceptance & 0.921 & 0.793 & Sedang \\
Purpose of Life & 0.877 & 0.692 & Sedang \\
Relationship with & & & \\
others & & & \\
\hline
\end{tabular}

Hasil analisis yang telah dilakukan diketahui bahwa butir item yang tidak memenuhi syarat validitas iaitu $\leq 0.3$ dinyatakan tidak valid. Setiap aspek pengukuran tersebut diatas didapati beberapa butir soalan yang dinyatakan gugur, iaitu soalan kepercayaan: T9 (-0.088) dan T10 (0.222); komunikasi: C1 (0.165), C8 (-0.371) dan C9 (0.017); Autonomy: A1 (0.176), Environmental Mastery: EM1 
(0.255), Personal Growth: PG1 (0.236), Self Acceptance: SE1 (0.290), dan Relationship with others: PR2 (0.242). Dengan demikian, diketahui hasil skor validitas pada masing-masing aspek pengukuran, aspek pengukuran pengasingan (alienation) menunjukkan validitas yang tidak valid dalam penelitian ini.

Tinggi atau rendahnya reliabilitas yang dinyatakan dengan angka koefisien reliabilitas, menunjukkan kesimpulan bahwa reliabilitas yang mendekati 1.00 dinyatakan sebagai koefisien reliabilitas yang baik (Bungin, 2013). Konsep reliabilitas berkaitan erat dengan masalah eror pengukuran (error measurement), iaitu inkonsistensi hasil ukur terjadi apabila pengukuran dilakukan ulang pada kelompok subjek yang sama (Azwar, 2013). Berdasarkan tabel 1 diketahui bahwa reliabilitas variabel kelekatan dan kesejahteraan psikologi menunjukkan perolehan reliabilitas dengan rentang sedang menuju kepada tinggi di setiap aspek pengukurnya.

Tabel 2 Pengujian Hipotesis korelasi sederhana dari Spearmen

\begin{tabular}{|c|c|c|c|c|c|c|}
\hline \multicolumn{7}{|c|}{ Correlations } \\
\hline & & & $\underline{\text { Kep }}$ & $\underline{\text { Kom }}$ & Keterasgn & $\frac{\text { Kesejahteraan }}{\underline{\text { Psikologi }}}$ \\
\hline \multirow{12}{*}{$\begin{array}{l}\text { Spearman's } \\
\text { rho }\end{array}$} & \multirow{3}{*}{ Kepercayaan } & Correlation Coefficient & 1,000 &, $670^{* *}$ &,$- 498^{* *}$ &, $311^{* *}$ \\
\hline & & Sig. (2-tailed) & &, 000 &, 000 &, 000 \\
\hline & & $\mathrm{N}$ & 352 & 352 & 352 & 352 \\
\hline & \multirow{3}{*}{ Komunikasi } & Correlation Coefficient &, $670^{* *}$ & 1,000 &,$- 320^{* *}$ & ,259** \\
\hline & & Sig. (2-tailed) &, 000 & 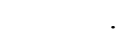 &, 000 &, 000 \\
\hline & & $\mathrm{N}$ & 352 & 352 & 352 & 352 \\
\hline & \multirow{3}{*}{ Keterasingan } & Correlation Coefficient &,$- 498^{* *}$ &,$- 320^{* *}$ & 1,000 &,$- 179^{* *}$ \\
\hline & & Sig. (2-tailed) &, 000 &, 000 & &, 001 \\
\hline & & $\mathrm{N}$ & 352 & 352 & 352 & 352 \\
\hline & \multirow{3}{*}{$\begin{array}{l}\text { Kesejahteraan } \\
\text { Psikologi }\end{array}$} & Correlation Coefficient &, $311^{* *}$ &, $259^{* *}$ &,$- 179^{* *}$ & 1,000 \\
\hline & & Sig. (2-tailed) &, 000 &, 000 &, 001 & \\
\hline & & $\mathrm{N}$ & 352 & 352 & 352 & 352 \\
\hline
\end{tabular}

\section{Analisis Statistik inferensial}

Analisis yang digunakan dalam penelitian ini adalah korelasi Spearman $\left(\mathrm{r}_{s}\right)$. Analisis ini dilakukan untuk menentukan hubungan dua variabel yang berskala ordinal atau jenjang. Distribusi probabilitas pensampelan menggunakan distribusi normal dengan statistik uji -Z. Apabila koefisien korelasi menunjukkan 
hubungan yang ditunjukkan dengan simbol $\mathrm{r}_{s}$, berarti terdapat jenis hubungan positif atau negatif signifikan diantara variabel yang diteliti. Hal ini dapat dilihat pada tabel 2 dibawah ini:

Berdasarkan analisis yang telah dilakukan diketahui bahwa kepercayaan remaja pada ibu yang bekerja berhubungan signifikan positif dengan aspek kelekatan komunikasi dan keseluruhan dimensi kesejahteraan psikologi. Samahal nya dengan aspek pengukuran kelekatan komunikasi remaja dengan ke enam dimensi kesejahteraan psikologi, berbanding terbalik dengan aspek pengukuran kelekatan pengasingan remaja pada ibu yang bekerja yang berhubungan signifikan negatif dengan keseluruhan dimensi kesejahteraan psikologi dan aspek pengukuran kelekatan lainnya (kepercayaan dan komunikasi).

Analisis selanjutnya dilakukan untuk menguji perbedaan antara variabel dimensi kelekatan dan kesejahteraan psikologi yang ditinjau berdasarkan jenis kelamin. Hasil analisis uji Mann-Whitney U digunakan dalam menjawab hipotesis selanjutnya, dapat dilihat pada tabel 3 dibawah ini:

Tabel 3a Hasil Pengujian uji beda dimensi variabel kelekatan dan kesejahteraan psikologi ditinjau dari jenis kelamin remaja

\begin{tabular}{crrrrr}
\hline & \multicolumn{5}{c}{ Test Statistics $^{\mathbf{a}}$} \\
\hline & Kepercayaan & Komunikasi & \multicolumn{1}{c}{ Keterasingan $^{\prime}$ PL } & \multicolumn{1}{c}{ Autonomy } \\
\hline Mann-Whitney & 13032,500 & 12089,500 & 12750,000 & 11748,000 & 12816,500 \\
Z &,- 924 & $-1,970$ & $-1,238$ & $-2,346$ & $-1,162$ \\
Asymp. Sig. (2- &, 355 &, 049 &, 216 &, 019 &, 245 \\
tailed) & 41955,50 & 42898,50 & 40011,00 & 39009,00 & 40077,00 \\
Laki-laki & 20172,50 & 1922,50 & 22117,00 & 23119,00 & 22050,00 \\
Perempuan & & & &
\end{tabular}

Tabel 3b (sambungan) Hasil Pengujian uji beda dimensi variabel kelekatan dan kesejahteraan psikologi ditinjau dari jenis kelamin remaja

\begin{tabular}{lrrrr}
\hline & \multicolumn{4}{c}{ Test Statistics $^{\mathbf{a}}$} \\
\hline PR & Env. Mas & \multicolumn{1}{c}{ PG } & \multicolumn{1}{c}{ SE } \\
\hline Mann-Whitney & 12761,000 & 12991,000 & 13845,000 & 12789,500 \\
Z & $-1,223$ &,- 968 &,- 021 & $-1,192$ \\
Asymp. Sig. (2-tailed) &, 221 &, 333 &, 984 &, 233 \\
Laki-laki & 40022,00 & 40252,00 & 41143,00 & 40055,50 \\
Perempuan & 22106,00 & 20985,00 & 20985 & 22077,00 \\
\hline
\end{tabular}

a. Grouping Variable: JK 
Berdasarkan tabel 3 diatas menunjukkan bahwa terdapat perbedaan komunikasi antara remaja laki-laki dan perempuan, hasil analisi Mann-Whitney U menunjukkan Z skor -1,970, signifikansi skor $p, 049<.05$. Sedangkan hasil analisis dimensi kepercayaan dan keterasingan menunjukkan hasil yang berbeda, karena Zskor menunjukkan -,924 dan skor $p$ menunjukkan ,355 >,05 pada dimensi kelekatan kepercayaan, sedangkan dimensi keterasingan menunjukkan Zskor $-1,238$ dan skor $p=, 216>, 05$ menunjukkan ketidaksignifikanan.

Hasil analisis Mann-Whitney U dimensi-dimensi kesejahteraan psikologi menunjukkan keberagaman hasil analisis ditinjau berdasarkan jenis kelamin, adapun hasil menunjukkan bahwa dimensi Purpose in life kesejahteraan psikologi remaja menunjukkan perbedaan yang signifikan antara remaja laki-laki dan perempuan, ini dibuktikan dari hasil analisis Zskor menunjukkan -2,346 dan skor $p$ menunjukkan ,019<,05. Sedangkan dimensi kesejahteraan psikologi lainnya seperti Autonomy, Positive relations with others, Environmental mastery, Personal growth, dan Self-acceptance menunjukkan hasil yang sebaliknya iaitu tidak signifikan atau tidak terdapat perbedaan kelima dimensi kesejahteraan psikologi antara remaja laki-laki dan perempuan.

Kehadiran orang tua, dalam hal ini Ibu pada saat dibutuhkan adalah fitur kunci dari kelekatan aman pada individu terutama remaja (Gamble \& Roberts, 2005). Kehadiran ibu secara fisik dapat mendorong individu untuk berpikir secara lebih rasional, membantu individu dalam memandu perilaku dan pikiran mereka, serta mengelola stres dengan strategi tertentu (Allen, 2008). Kehadiran ibu mengajarkan tentang kebaikan, serta kepercayaan dan kontinuitas sikap yang lebih baik, disebutkan bahwa apabila antara ibu dan remaja tidak saling memupuk kepercayaan satu dengan lainnya, mereka akan lebih mengasingkan diri terhadap perasaan dan impian nya (Ishak et al, 2010). Kepercayaan membina sensitivitas ibu terhadap kebutuhan anak/remaja, sehingga mewujudkan perasaan aman pada remaja (Armsden \& Geenberg, 1987; Ishak et al, 2010). Menurut para peneliti sebelumnya pula, kepercayaan yang diwujudkan dari kelekatan remaja kepada ibu bekerja menunjukkan pemahaman, rasa hormat dan responsif dari ibu untuk 
memahami kebutuhan, keinginan dan persepsi remaja, sehingga dapat merepresi segala keinginan dan hasrat negatif yang ada pada individu.

Membangun kualitas komunikasi dua arah antara ibu dan remaja membantu perkembangan remaja secara kognitif, sosial dan emosional, hasil penelitian ini juga telah menunjukkan bahwa respon pada aspek pengukuran kelekatan komunikasi yang tinggi. Menurut beberapa peneliti kelekatan, komunikasi yang dijalankan secara konstan, tidak berubah-ubah, aktif dan interaktif membantu individu dalam beradaptasi dan menerima keadaan lingkungan lebih baik, dibandingkan dengan kelekatan komunikasi secara pasif, dan selalu berubah-ubah (Ackard, Neumark-Sztainer, Story, \& Perry, 2010). Komunikasi yang efektif antara ibu bekerja dan remaja sangat penting dalam mengembangkan kelekatan yang lebih sehat, selain itu pula mengembangkan kepercayaan antara dua individu selama periode mereka berinteraksi (Ishak et al, 2010).

\section{Kesimpulan}

Berdasarkan pengolahan data dan analisis yang telah dilakukan penelitian ini telah menunjukkan bahwa terdapat interaksi positif yang signifikan di antara variabel yang ada. Selain itu juga ditunjukkan nilai koefisien korelasi keeratan hubungan antara variabel terikat dan variabel bebas. Hasil yang telah dijelaskan juga didukung oleh penelitian-penelitian terdahulu yang memiliki keterkaitan variabel yang diukur. Kehadiran orang tua, dalam hal ini Ibu pada saat dibutuhkan adalah fitur kunci dari kedekatan aman pada individu terutama remaja Membangun kualitas komunikasi dua arah antara ibu dan remaja membantu perkembangan remaja secara kognitif. Komunikasi yang efektif antara ibu bekerja dan remaja sangat penting dalam mengembangkan kedekatan yang lebih sehat, selain itu pula mengembangkan kepercayaan antara dua individu selama periode mereka berinteraksi. 


\section{DAFTAR PUSTAKA}

Albert, I., Trommosdoff, G., \& Mishra, R. (2007). Parenting and Adolescent attachment in India and Germany. Selected Papers from the Seventeenth International Congress of the International Association for Cross-Cultural Psychology.

Allen, T. D. 2013. The work-family role interface: a synthesis of the research from industrial and organizational psychology. In Handbook of Psychology, $2^{\text {nd }}$, pp. 698-718 edited by I. B. Weiner. John Willey \& Sons. Inc.

Armsden, G. C., \& Greenberg, M. T. (1987). The inventory of parent attachment: Individual differences and their relationship to psychological well-being in adolescence. Journal of Youth and Adolescence, 16, 427-455

Badan Pusat Statistik (2013). Pusat Statistik Seluruh Indonesia.

Boniwell, I., \& Henry, J. (2007). Developing conceptions of well-being:advancing subjective, hedonic and eudaimanic theories. Social Psychological Review, 9 (10), 3-18.

Bowlby, J. (1969). Attachment. Attachment and loss: Vol. 1. Loss. New York: Basic Books

Bowlby, J. (1982). Attachment and Loss. Vol 1 attacment. $2^{\text {nd }}$ ed Tavistock Institute Of Human Relations.

Bradburn, N. M (1996) The structure of psychological well-being. National Opinion Research Center; Monographs in Social Research: Aldine Pub Co. Chicago.

Gennetian, L., \& Miller, C. (2002). Children and welfare reform: A view from an experimental welfare program in Minnesota. Child Development, 73, 601620 .

Heinrich, C. J. 2014. Parents' employment and children's wellbeing. The Future of Children, vol. 24 (1), 121-146.

Ishak, N. M., Yunus, M. Md., \& Iskandar, I. P. (2010) Trust, Communication and Healthy parental attachement among Malaysian academically talented college students. Procedia Social and Behavioral Sciences, 9, 529-1536.

Kalil, A., \& Siol-Guest, K. M. (2004). Single mothers' employment dynamics and adolescent well-being. National Poverty Center Working Paper Series. Available online http://www.npc.umich.edu/publications/working papers. 
Lyubomirsky, S., King, L., \& Diener, E (2005) The benefits of frequent positive affect: Does happiness lead to success? Psychological Bulletin, vol. 131, pp.803-855.

Montemayor, R., \& Clayton, M. D. (2001). Maternal employment and adolescent development. Journal of Early Adolescence, 24 (1), 6-8.

Nomaguchi, K.M., Milkie, M.A., \& Bianchi, S.M. (2005). Time strains and psychological wellbeing: Do dual-earner mothers and fathers differ? Journal of Family Issues, 26(6), 756-792.

Rothbaum, F., Weisz, J., Pott, M., Miyake, K., \& Morelli, G. (2000). Attachment and culture: Security in the United States and Japan. American Psychologist. $55,1093-1104$.

Ryff, C. D., \& Singer, B. (1996). Psychological well-being: Meaning, Measurement, and Implication for Psychotherapy Research. Psychoterapy Psychosomatism, 65, 14-23.

Ryff, C. D., Singer, B. H., \& Love, G. D (2008) Positive health: Connecting wellbeing with biology. Philosophical Transactions of The Royal Society of London, no. 359, pp.1383-1394.

Ryff, C. D., Singer, B. H., \& Love, G. D (2004) Positive health: Connecting wellbeing with biology. Philosophical Transactions of The Royal Society of London, no. 359, pp.1383-1394.

Ryff, C.D., \& Keyes, C. L. M (1995) The Structure of psychological well-being revisited. Journal of Personality and Social Psychology, vol.69 (4), pp. 719727.

Veenhoven, R. (1991). Is happiness relative ? Social Indicators Research, 24, 134. 